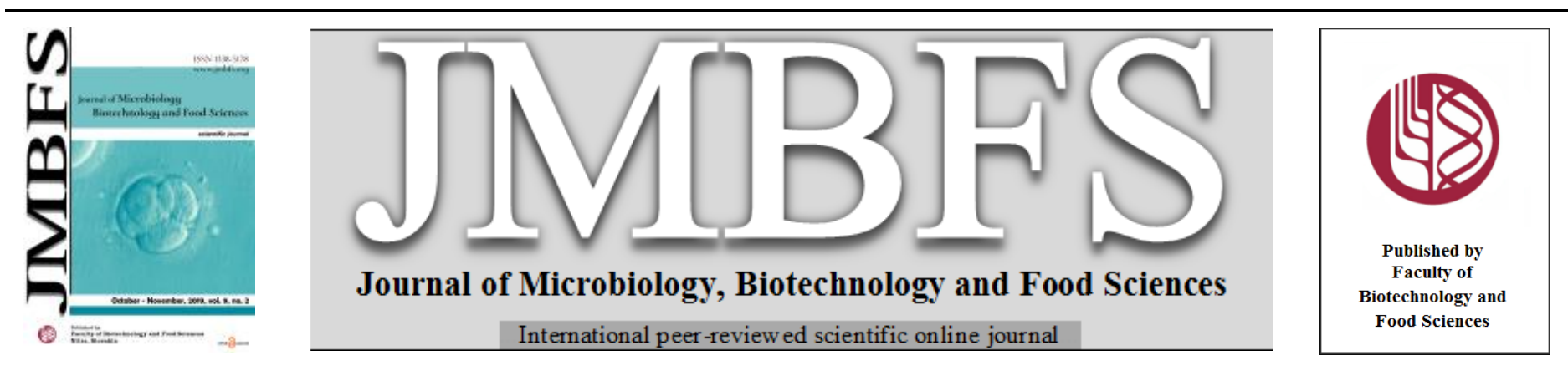

\title{
ISOLATION AND CHARACTERIZATION OF t-RESVERATROL AND $\alpha$-VINIFERIN, A BIOACTIVE SECONDARY METABOLITE OF AN ENDOPHYTIC FUNGUS ASPERGILLUS STELLIFER AB4, FROM VITIS VINIFERA
}

\author{
Chetana Roat and Meenu Saraf \\ Address(es): Department of Microbiology \& Biotechnology, University School of Sciences, Gujarat University, Ahmedabad-380 009, India.
}

*Corresponding author: chetana.roat@gmail.com

doi: $10.15414 / j m b f s .2020 .9 .4 .708-713$

\section{ARTICLE INFO}

Received 24. 4. 2019

Revised 16. 10. 2019

Accepted 23. 10. 2019

Published 3. 2. 2020

Regular article OPEN $\partial_{\text {ACCESS }}$

\begin{abstract}
The secondary metabolite t-resveratrol and $\alpha$-viniferin is widely recognized bioactive molecules that is known for preventing and slowing the occurrence of many diseases, have attracted great research interest. The aim of this work is to isolate the endophytic microorganisms that possess t-resveratrol and $\alpha$-viniferin producing capability from the plants of Vitaceae family: Vitis vinifera, Vitis quinquangularis Rend and Cayratia trifolia. Twenty isolates were obtained from the different tissues of all the three plants and all were able to produced t-resveratrol and $\alpha$-viniferin in different concentrations in their consecutives second subcultures. Aspergillus stellifer AB4 isolated from leaf of Vitis vinifera had shown stable production capability of t-resveratrol $288 \mu \mathrm{g} / \mathrm{L}$ and $\alpha$-viniferin $301 \mu \mathrm{g} / \mathrm{L}$ in liquid culture, while 19 isolates producing capability diminished after third subculture. Optimization of the conditions for t-resveratrol and $\alpha$-viniferin production by A. stellifer AB4 were studied, an inoculum size of $10 \% \mathrm{v} / \mathrm{v}\left(2 \times 10^{4}\right)$ spore number $/ \mathrm{ml}$, a rotation speed of $100 \mathrm{rpm}$, and a temperature of $28^{\circ} \mathrm{C}$ and $\mathrm{pH} 7$ was optimum for the production of t-resveratrol and $\alpha$-viniferin. Growth of A. stellifer AB4 increased during cultivation, reached high level of biomass $1.98 \pm 1.7$ on $7^{\text {th }}$ day and the highest production of t-resveratrol 300 $\mu \mathrm{g} / \mathrm{L}$ and $\alpha$-viniferin $324 \mu \mathrm{g} / \mathrm{L}$ was reached on 9 day of fermentation. This work indicates that endophytic fungi A. stellifer AB4 is expected to be potential source of bioactive molecules t-resveratrol and $\alpha$-viniferin.
\end{abstract}

Keywords: t-resveratrol, $\alpha$-viniferin, Endophytes , Aspergillus, HPLC

\section{INTRODUCTION}

Endophytes reside within the specific chemical environment of host plant tissue and adapt the plant physiology in order to produce the bioactive molecules like secondary metabolites same as the plant produced. They colonize inside the living plant tissue without causing any harmful effect to the host plant (Albert et al., 1990). The endophytes establish either mutualisms or antagonistic relationship with the host plants. Host plant restrict the growth of endophytes utilize many mechanism to adapt its living environment. The studies on endophytes, especially in the field of disease management of humans and plants, are currently emerging to forefront. The microorganisms like fungi and bacteria have been reported as endophytes for the production of bioactive secondary metabolites. The most commonly known endophytes are fungi for production of bioactive secondary metabolites production (Aly et al., 2011).

The plant derivative metabolites such as t-resveratrol (3,5,4'-trihydroxystilbene) and $\alpha$-viniferin are commonly used as medicinal ingredient and nutritional supplements. They are a small class of polyphenol stilbenes and are derived from the phenylpropanoid acid including cinnamic acid and p-coumaric acid that derived from aromatic amino acid phenyalanine, called as phenylpropanoid pathway by Roat and Ramawat (2009). These two molecules are gaining much scientific attention due to its pharmacological, biological, neutriceuticals values and in treatment of metabolic syndromes (Cherniack, 2011; Xianfeng-Huang et al., 2011; Zhu et al., 2011). Epidemiological studies proved that moderate consumption of red wine containing reseveratrol reduces the risk of coronary heart disease, cancer, platelets thrombus formation, Alzheimer's disease refereed as "French Paradox" (Chen et al., 2013).

First time the resveratrol and its derivatives were isolated from the white hellebore, Veratrum grandiflorum O. Loes in 1939 (Takaoka M, 1939). Later it has also been reported in root extract of the Japanese Knotweed Polygonum cuspidatum syn. Fallopia japonica, which is known as a Chinese herbal medicine, well-known commercial source of resveratrol (Nonomura et al., 1963). Subsequently, the presence of stilbenes molecules like t-resveratrol and $\alpha$ viniferin also reported their presence in the plants of Vitaceae family (Baur $\boldsymbol{e t}$ al., 2006). Grapes from the plant Vitis vinifera is the best and the most important dietary sources of these stilbenes (Goldberd et al., 1996).
This is the first report of endophytic fungi A.stellifer AB4, being isolated from the plant Vitis vinifera, and used for the production and optimization of tresveratrol and $\alpha$-viniferin. Biosynthesis of $t$-resveratrol and $\alpha$-viniferin by using endophytic microorganisms is a novel approach, in microbial biotechnology as it can be used to produce round the year within shorter turnover period of production time. The shortage of plant material from where t-resveratrol and $\alpha$ viniferin is being extracted and the time it takes to grow the plants make this new microbial method more viable and advantageous, subsequently, less information is available for production of stilbenes from endophytes.

\section{MATERIAL AND METHOD}

\section{Chemicals}

Standards Compounds: trans-t-resveratrol and $\alpha$-viniferin were purchased from Sigma.

All chemicals used for extraction and purification were of AR grade Merck.

Thin-layer chromatography (TLC) was performed using percolated silica gel 60 GF254 plates

\section{Plant Materials}

Microbial endophytes where isolated from three grape plants from Vitaceae family, (i) Vitis Vinifera L. cv. Merlot (cultivar Merlot) (ii) Vitis quinquangularis Rehd and (iii) Cayratia trifolia (wild Vitis) were collected from three States of India (Gujarat, Rajasthan and Maharastra) during June to October. Different parts of plant like stems, leaves, and fruits were gathered for further studies as these plants were known for the secretion of $t$-resveratrol and $\alpha$-viniferin.

\section{Media}

Four different types of media were used for isolation and screening of endophytes : Potato dextrose agar (PDA: potato (peeled and diced) $300 \mathrm{~g}$, dextrose $20 \mathrm{~g}$, agar $20 \mathrm{~g}$, and water $1 \mathrm{~L}$ ) Beef-protein medium (BP: beef extract $3 \mathrm{~g}$, peptone $10 \mathrm{~g}$, $\mathrm{NaCl} 5 \mathrm{~g}$, agar $20 \mathrm{~g}$, and distilled water $1 \mathrm{~L} ; \mathrm{pH}$ 7.4-7.6), Gause medium G1(GA1: soluble starch $20 \mathrm{~g}, \mathrm{KNO} 31 \mathrm{~g}$, K2HPO4 $0.5 \mathrm{~g}, \mathrm{MgSO} 4 \cdot 7 \mathrm{H} 2 \mathrm{O} 0.5 \mathrm{~g}$, 
$\mathrm{NaCl} 0.5 \mathrm{~g}$, FeSO4·7H2O $0.01 \mathrm{~g}$, agar $20 \mathrm{~g}$, and distilled water $1 \mathrm{~L} ; \mathrm{pH}$ 7.4-7.6) and Nutrient agar. The liquid form of these media were used to quantify the $\mathrm{t}$ resveratrol and $\alpha$-viniferin production by the isolates. Further specified media Czapek yeast extract agar medium (sucrose $30 \mathrm{~g}$, yeast extract $5 \mathrm{~g}$, NaNO33 g, $\mathrm{KCl} 0.5 \mathrm{~g}, \mathrm{MgSO}_{4} \cdot 7 \mathrm{H}_{2} \mathrm{O} 0.5 \mathrm{~g}, \mathrm{FeSO}_{4} \cdot 7 \mathrm{H}_{2} \mathrm{O} 0.01 \mathrm{~g}, \mathrm{~K}_{2} \mathrm{HPO}_{4} 1 \mathrm{~g}$, agar $20 \mathrm{~g}$, and water $1 \mathrm{~L}$ ) was used for the further strains identification of the genera Alternaraia, Aspergillus and Penicillium (Pereyra et al., 2011)

\section{Endophytes Isolation}

Endophytes were isolated from the stems, leaves, fruits of Vitis vinifera, Vitis quinquangularis and Cayratia trifolia. All samples were surface sterilization by $7 \%$ of sodium hypochlorite for 5-7 minutes under aseptic conditions and inoculated on BP, GA1, PDA and NA medium (Larran et al., 2002; Naik et al. 2009) Xing and Guo (2011), the inoculated plates were kept at $28 \pm 1{ }^{\circ} \mathrm{C}$ under dark conditions. The colonies were subculture on fresh medium from which the isolates were obtained for further purification. All experiments for each test were conducted in triplicate.

\section{Screening of endophytes for t-resveratrol and $\alpha$-viniferin production}

Morphological study was done for all the endophytes isolated, containing bacteria and fungi. All the isolates obtained were inoculated in $100 \mathrm{~mL}$ of the respective liquid medium having $1 \%$ inoculums size and kept under dark conditions at $28 \pm 1{ }^{\circ} \mathrm{C}$ on shaker with $100 \mathrm{rpm}$ for 6-7 days, centrifuged at $3000 \times$ $\mathrm{g}$ for $15 \mathrm{~min}$ was done for separation of cells from the liquid. The liquid nitrogen was used to crush the cells and then extracted with acetone: water (60:40) to obtain the t-resveratrol and $\alpha$-viniferin from inside the cells. The extract was concentrated under vacuum below $40^{\circ} \mathrm{C}$ till the complete removal of acetone. The aqueous phase was, then partitioned three times with $20 \mathrm{~mL}$ ethyl acetate; finally the ethyl acetate phase was concentrated under vacuum till dryness. This extract was used for the next steps of separation.

\section{TLC and HPLC measurement}

The extract of bacterial and fungal culture was dissolved in methanol and used for TLC profile. $10 \mu 1$ of authentic samples of t-resveratrol, $\alpha$-viniferin and isolated extract were applied on pre-coated silica gel $60 \mathrm{~F}_{254}$ TLC plate $(0.2 \mathrm{~mm}$ Merk5554). The plate were kept in the mobile phase of chloroform: $\mathrm{MeOH}$ Water : ethyl: actetate ( 85:15:3.v/v). The plates were air dried and observed under visible and UV Light.

Separation of t-resveratrol and $\alpha$-viniferin was done by HPLC with the following method: Solvent A- $0.0025 \%$ trifluoro acetic acid in water; solvent B-80\% acetonitrile (E. Merck, India) in solvent A. The mobile phase consisted of solvent (A) and (B). The step gradient programme of solvent A was as follows: 0-3 min: 86\%-82\%; 3-12 min: $82 \%-82 \%$; $12-25 \mathrm{~min}: 82 \%-78 \%$; $25-30 \mathrm{~min}: 78 \%-78 \%$ 30-38 min: $78 \%-60 \%$; $38-43 \mathrm{~min}: 60 \%-60 \%$; $43-46 \mathrm{~min}: 60 \%-40 \%$; $46-48 \mathrm{~min}$ 40\%-30\%; 48-50 min: 30\%-30\%; 50-52 $\min : 30 \%-20 \% ; 52-54 \min : 20 \%-20 \% ; 54$ 56 min: 20\%-15\%; $56-58 \mathrm{~min}: 15 \%-0 \%$;58-60 :0-0\%; 60-62 min: 0\%-86\%; 62 65 min: $86 \%-86 \%$. Flow rate of $1.0 \mathrm{ml} \mathrm{min}^{-1}$ and chromatographic peak monitored at $\lambda$ exc $300 \mathrm{~nm}$ and $\lambda$ em $390 \mathrm{~nm}$ using fluorescence detector. The spent medium was extracted with $100 \mathrm{ml}$ ethyl acetate and analysed by HPLC for t-resveratrol and $\alpha$-viniferin released in the medium (Roat et al 2009).

The Standard compounds were dissolved in methanol to yield a fina concentration of $1.0 \mathrm{mg} \mathrm{ml}^{-1}$ and standard curve were prepared for both the molecules with concentration ranging from 25 to $1200 \mathrm{ng} \mathrm{ml}^{-1}$. The amount of the compound were calculated on the basis of their standard curve.

\section{Identification of t-resveratrol and $\alpha$-viniferin producing endophytic fungus}

The morphological identification and microscopy study and molecular identification of the isolated strain was done (Yuan et al., 2011; Dey et al 2011; Suetsuna et al., 1990). Fungi Identification PCR Kit (TaKaRa, Kyoto, Japan) and primers, ITS5: GGAAGTAAAAGTCGTAASAAKG and ITS4 TCCTCCGCTTATTKATDTGC', were used for Genomic DNA study.

Profiles of cell culture growth of isolated species for t-resveratrol and $\alpha$ viniferin production

t-resveratrol and $\alpha$-viniferin production was carried out in vitro in $100 \mathrm{~mL}$ liquid Czapek yeast extract medium in a $250-\mathrm{mL}$ flask at $28^{\circ} \mathrm{C}$ with a rotation speed of $100 \mathrm{rpm}$ and the cell growth profile of isolated strain was studied. The distribution of t-resveratrol and $\alpha$-viniferin both intracellular and extracellular was done at days 5 and 7 within the cultures and their study was done by similar extraction method. Dry mass of cells were measured at every day after drying the mycelia at $50{ }^{\circ} \mathrm{C}$ for $48 \mathrm{~h}$, and the production of t-resveratrol and $\alpha$-viniferin measured using the above mentioned methods from days 3 to 20 of cultivation. The resulting t-resveratrol and $\alpha$-viniferin content in the liquid culture (micrograms / litre) and within the cells (micrograms / gram) was determined and reported as the average of three parallel samples.
Optimization of physicochemical parameters for production of t-resveratrol and $\alpha$-viniferin

Optimization of time course study, $\mathrm{pH}$, and incubation period and inoculums size was studied. The isolated strain $\mathrm{AB} 4$ was inoculated into Czapek yeast extract (CYE) agar medium and grown at range of temperatures varying from $15^{\circ} \mathrm{C}$ to 48 ${ }^{\circ} \mathrm{C}$. Aspergillus strain $\mathrm{AB} 4$ growth and synthesis of t-resveratrol, $\alpha$-viniferin at each temperature was determined (Thompson et al., 1997). Different $\mathrm{pH}$ values ranging from 3 to 11 were used after adjusting $\mathrm{pH}$ of the CYE medium. The effect of incubation period was determine from 3 to 20 days for the growth and active metabolite production by the isolated strain. To determine inoculums size, the culture flasks were also inoculated separately with inoculums volume 5\%, $10 \%, 15 \%, 20 \%$ spores ranging from $1 \times 10^{4}, 2 \times 10^{4}, 3 \times 10^{4}, 4 \times 10^{4}$ (spores $/ \mathrm{ml}$ ), for growth and production of t-resveratrol and $\alpha$-viniferin by strain AB4. Each experiment was carried out in triplicate.

\section{Statistical Analysis}

All results were averaged over three separate analyses from three flasks for the estimation of t-resveratrol and $\alpha$-viniferin and three consecutive experiments with six replicate flasks in each treatment for growth value determination. The results were expressed as $\mathrm{g} / \mathrm{L}$ of cell growth.

\section{RESULT AND DISCUSSION}

\section{Identification and Production of t-resveratrol and $\alpha$-viniferin by isolated} endophytes

Vitis vinifera, Cayratia trifolia and Vitis quinquangular were studied, total of twenty isolates were obtained from these three plants, ten from Vitis vinifera, five from Cayratia trifolia, and five from Vitis quinquangularis (Table I). Fifteen isolates were identified as fungi and remaining five were bacteria. Among all the isolates, the only one fungal isolate which was isolated from the leaf of Vitis vinifera produced maximum t-resveratrol $(300 \mu \mathrm{g} / \mathrm{L})$ and $\alpha$-viniferein $(324 \mu \mathrm{g} / \mathrm{L})$ The chemical structure of t-resveratrol and $\alpha$-viniferin (Figure I). The production of t-resveratrol and $\alpha$-viniferin gradually decreased for few isolates after second and third subculture. The only one fungal strain AB4, isolated from leaf of Vitis vinifera plant was stable and retained the production capability on CYE medium.

Table 1 Endophytes isolated from Vitis vinifera, Vitis quinquangularis, Cayratia trifolia

\begin{tabular}{|c|c|c|c|c|c|}
\hline Plant & Strain & Types & Tissue & Medium & $\begin{array}{c}\text { Number of } \\
\text { isolates }\end{array}$ \\
\hline \multirow{9}{*}{$\begin{array}{l}\text { Vitis vinifera } \\
(\mathrm{AB})\end{array}$} & $\mathrm{AB} 1$ & Bacterium & $\begin{array}{c}\text { Skin of } \\
\text { fruit }\end{array}$ & BP & 1 \\
\hline & $\mathrm{AB} 2$ & Bacterium & Stem & GA & 1 \\
\hline & AB3 & Bacterium & Leaf & NA & 1 \\
\hline & $\mathrm{AB} 4$ & Fungus & Leaf & PDA & 1 \\
\hline & AB5 & Fungus & Stem & PDA & 1 \\
\hline & AB6 & Fungus & $\begin{array}{c}\text { Skin of } \\
\text { fruit }\end{array}$ & GA & 1 \\
\hline & $\mathrm{AB} 7$ & Fungus & Tendril & PDA & 1 \\
\hline & AB8 & Fungus & $\begin{array}{c}\text { Seed of } \\
\text { friut }\end{array}$ & PDA & 1 \\
\hline & AB9 & Fungus & Cob & PDA & 1 \\
\hline \multirow{6}{*}{ Cayratia trifolia } & $\mathrm{AB} 10$ & Fungus & Root & PDA & 1 \\
\hline & CD1 & Bacterium & Leaf & $\mathrm{BP}$ & 1 \\
\hline & $\mathrm{CD} 2$ & Bacterium & Stem & NA & 1 \\
\hline & CD3 & Fungus & Cob & GA & 1 \\
\hline & CD4 & Fungus & Fruit & GA & 1 \\
\hline & CD5 & Fungus & Root & PDA & 1 \\
\hline \multirow{5}{*}{$\begin{array}{l}\text { Vitis } \\
\text { quinquangularis }\end{array}$} & EF1 & Bacterium & Fruit & $\mathrm{BP}$ & 1 \\
\hline & $\mathrm{EF} 2$ & Fungus & Stem & GA & 1 \\
\hline & EF3 & Fungus & $\mathrm{Cob}$ & GA1 & 1 \\
\hline & EF4 & Fungus & Root & PDA & 1 \\
\hline & EF6 & Fungus & Leaf & PDA & 1 \\
\hline
\end{tabular}


(A)

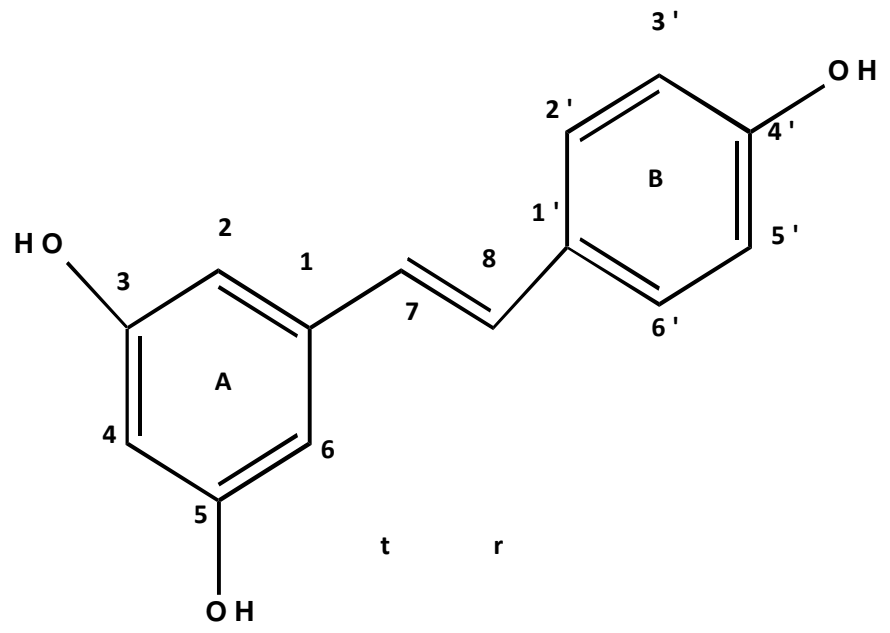

Figure 1 Chemical structure of (A) t-resveratrol $\left(\mathbf{C}_{14} \mathbf{H}_{12} \mathbf{O}_{3}\right)$ (B) $\alpha$-viniferin $\left(\mathrm{C}_{28} \mathrm{H}_{23} \mathrm{O}_{6}\right)$

Alternaria (Five strains), Penicillium (Six strain strains), Cephalosporium (Three strains), Aspergillus (Six strains) selected for t-resveratrol and $\alpha$-viniferin production (Table II). Maximum production of t-resveratrol and $\alpha$-viniferin was studied by Aspergillus strain AB4, which showed highest production of both the compounds. Strain AB4 isolated from leaf of Vitis vinifera on CYE agar medium, reaching $16-18 \mathrm{~mm}$ in 7 days, and $25-35 \mathrm{~mm}$ in diameter in 14 days at $25^{\circ} \mathrm{C}$. Initially light brown, later becoming dark brown, centrally rising, close textured, velvety, with regular margins. The colony growth showed a concentric appearance with the mycelium showed subhylaine branches. Conidiophores were $100-250 \times 4.5-6 \mu \mathrm{m}$, vesicle: hemispherical, $10-15 \mu \mathrm{m}$, merging into supporting conidiophores, biseriate sterigmata, primaries crowed, parallel 6-7 $\times 2-3 \mu \mathrm{m}$, second arise closely packed 5-7 $\times 1-2 \mu \mathrm{m}$. These morphological characteristics were resembles with genus Aspergillus (Figure II).

(B)

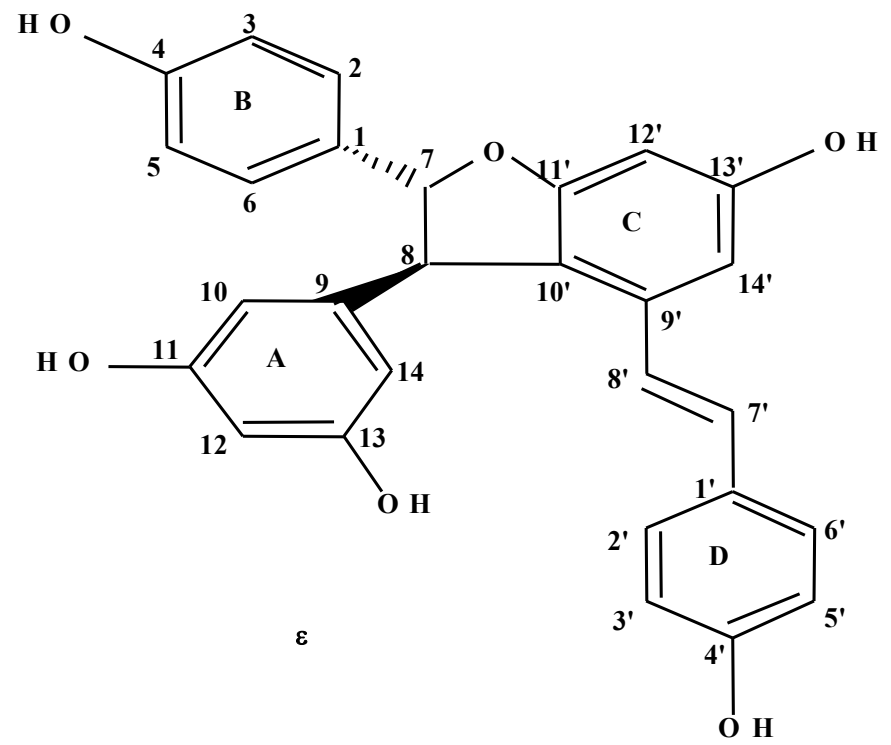

Table 2 t-resveratrol and $\alpha$-viniferin producing fungi

\begin{tabular}{|c|c|c|c|c|c|c|c|c|c|}
\hline \multirow[t]{3}{*}{ Plant } & \multirow[t]{3}{*}{ Tissue } & \multirow[t]{3}{*}{ Strain } & \multirow[t]{3}{*}{ Genus } & \multicolumn{3}{|c|}{$\begin{array}{c}\text { t-resveratrol } \\
\text { production }(\mu \mathrm{g} / \mathrm{L})\end{array}$} & \multicolumn{3}{|c|}{$\begin{array}{c}\alpha \text {-viniferin } \\
\text { production }(\mu \mathrm{g} / \mathrm{L})\end{array}$} \\
\hline & & & & \multicolumn{6}{|c|}{ No. of Subcultures } \\
\hline & & & & $\mathbf{I}$ & II & III & I & II & III \\
\hline \multirow{12}{*}{ Vitis vinifera } & Fruit & $\overline{\text { AB1 }}$ & Penicillium & $122 \pm 2$ & $129 \pm 4$ & $10 \pm 2$ & $112 \pm 3$ & $122 \pm 2$ & $122 \pm 6$ \\
\hline & Stem & AB2 & Alternaria & $125 \pm 3$ & $135 \pm 4$ & $112 \pm 2$ & $113 \pm 3$ & $111 \pm 3$ & $10 \pm 2$ \\
\hline & Leaf & AB3 & Aspergillus & $145 \pm 1$ & $155 \pm 5$ & $160 \pm 3$ & $115 \pm 2$ & $132 \pm 4$ & $140 \pm 2$ \\
\hline & Leaf & AB4 & Aspergillus & $115 \pm 5$ & $165 \pm 3$ & $288 \pm 3$ & $120 \pm 3$ & $155 \pm 5$ & $301 \pm 4$ \\
\hline & Stem & AB5 & Alternaria & $116 \pm 3$ & $143 \pm 2$ & $118 \pm 7$ & $15 \pm 3$ & $11 \pm 4$ & $\mathbf{0} \pm 2$ \\
\hline & $\begin{array}{c}\text { Skin of } \\
\text { fruit }\end{array}$ & AB6 & Cephalosporium & $117 \pm 4$ & $134 \pm 3$ & $116 \pm 7$ & $14 \pm 3$ & $28 \pm 4$ & $\mathbf{0} \pm \mathbf{1}$ \\
\hline & Tendril & AB7 & Penicillium & $117 \pm 2$ & $120 \pm 4$ & $123 \pm 4$ & $20 \pm 4$ & $45 \pm 3$ & $20 \pm 4$ \\
\hline & Friut & AB8 & Alternaria & $13 \pm 3$ & $14 \pm 4$ & $12 \pm 3$ & $\mathbf{0} \pm \mathbf{0}$ & $\mathbf{0} \pm \mathbf{0}$ & $\mathbf{0} \pm \mathbf{0}$ \\
\hline & Cob & AB9 & Aspergillus & $111 \pm 2$ & $123 \pm 4$ & $131 \pm 4$ & $18 \pm 4$ & $16 \pm 3$ & $21 \pm 2$ \\
\hline & Root & AB10 & Penicillium & $12 \pm 2$ & $12 \pm 0$ & $16 \pm 5$ & $0 \pm 0$ & $\mathbf{0} \pm \mathbf{0}$ & $0 \pm 0$ \\
\hline & Leaf & CD1 & Aspergillus & $12 \pm 4$ & $121 \pm 4$ & $140 \pm 2$ & $22 \pm 3$ & $167 \pm 2$ & $78 \pm 3$ \\
\hline & Stem & CD2 & Alternaria & $114 \pm 4$ & $121 \pm 3$ & $126 \pm 3$ & $130 \pm 3$ & $127 \pm 5$ & $86 \pm 5$ \\
\hline \multirow[t]{5}{*}{ Catratia trifolia } & Cob & CD3 & Cephalosporium & $10 \pm 2$ & $\mathbf{0} \pm \mathbf{1}$ & $\mathbf{0} \pm 2$ & $18 \pm 2$ & $46 \pm 4$ & $43 \pm 4$ \\
\hline & Fruit & CD4 & Penicillium & $132 \pm 3$ & $132 \pm 3$ & $154 \pm 3$ & $32 \pm 2$ & $51 \pm 3$ & $40 \pm 7$ \\
\hline & Root & CD5 & Penicillium & $112 \pm 3$ & $121 \pm 3$ & $152 \pm 5$ & $12 \pm 3$ & $13 \pm 4$ & $38 \pm 5$ \\
\hline & Fruit & EF1 & Aspergillus & $112 \pm 2$ & $124 \pm 4$ & $136 \pm 5$ & $42 \pm 3$ & $18 \pm 4$ & $11 \pm 3$ \\
\hline & Stem & EF2 & Cephalosporium & $\mathbf{0} \pm 3$ & $\mathbf{0} \pm \mathbf{1}$ & $0 \pm 5$ & $32 \pm 2$ & $16 \pm 3$ & $15 \pm 2$ \\
\hline \multirow[t]{3}{*}{ Vitis quinquangularis } & Cob & EF3 & Alternaria & $132 \pm 4$ & $138 \pm 3$ & $143 \pm 2$ & $\mathbf{0} \pm \mathbf{1}$ & $0 \pm 2$ & $3 \pm 3$ \\
\hline & Root & EF4 & Aspergillus & $143 \pm 2$ & $145 \pm 4$ & $140 \pm 7$ & $\mathbf{0} \pm \mathbf{1}$ & $26 \pm 3$ & $14 \pm 3$ \\
\hline & Leaf & EF5 & Penicillium & $0 \pm 2$ & $0 \pm 4$ & $0 \pm 3$ & $12 \pm 3$ & $16 \pm 2$ & $18 \pm 3$ \\
\hline
\end{tabular}




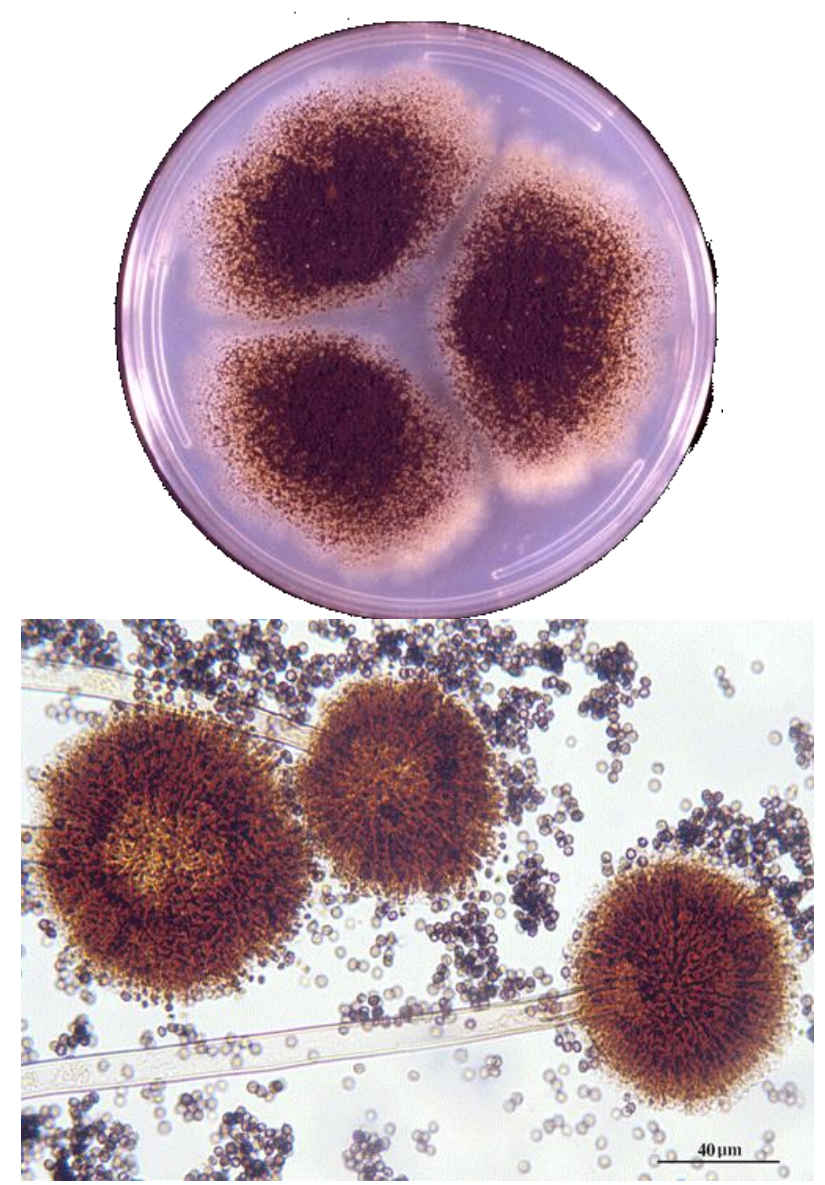

Figure 2 Morphology of Aspergillus stellifer AB4

The DNA sequence of the ITS regions of fungal strain AB4, together with the $18 \mathrm{~S}$ rRNA, was 573 bp long and archived in the Gene Bank database under the accession number KT258010. Closest related species available at Gene Bank with the ITS sequence data for strain AB4, which was identified as Aspergillus stellifer (Figure III) and were used for the construction of a phylogenetic tree Saitou and Nei, (1987) (Tamura et al., 2007; Huang et al., 2001).

(A)

$$
1 \mathrm{~L}
$$

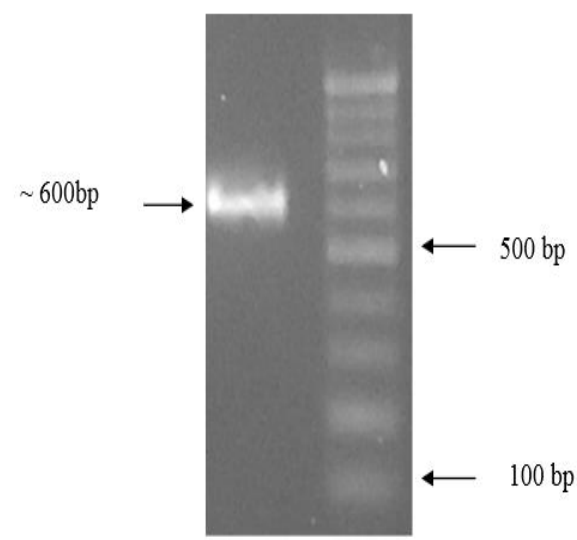

PCR amplification of ITS region from fungal sample. The size of PCR amplified product is $\sim 600 \mathrm{bp}$
(B)

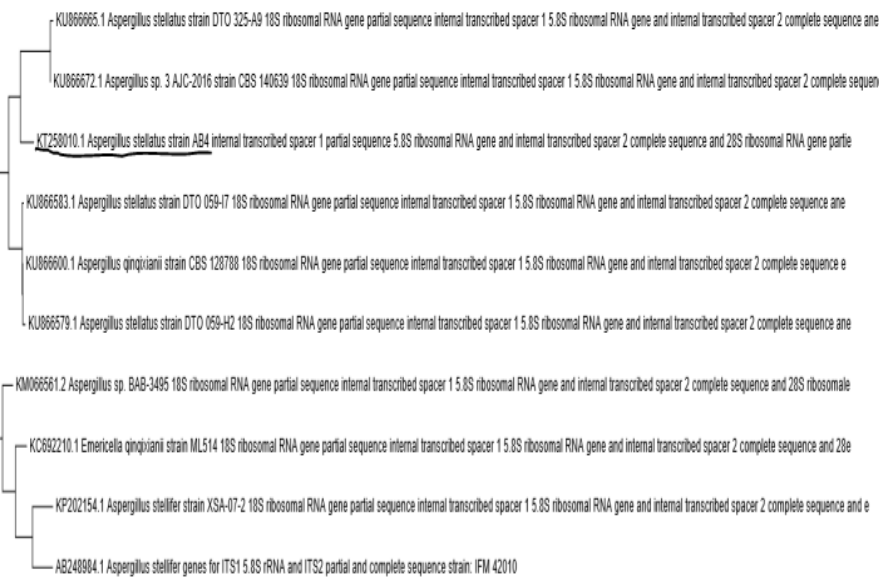

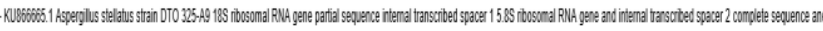

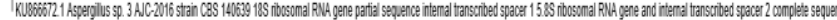

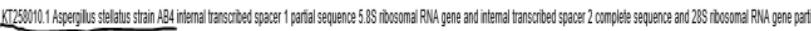

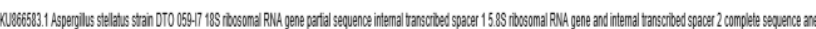

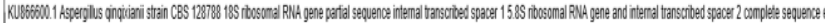

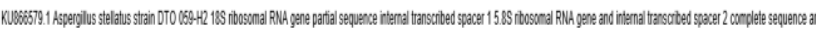

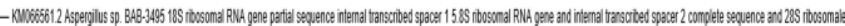

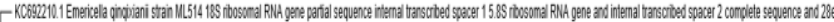

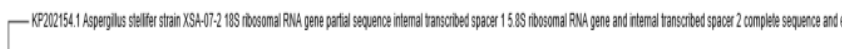

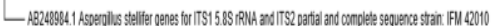

tos

Figure 3 (A) PCR amplified 18S rDNA ITS region (B) Phylogenetic tree of the Aspergillus sp. AB4 and related organisms

Profiles of cell culture growth of Aspergillus stellifer AB4 for t-resveratrol and $\alpha$-viniferin production

The highest cell mass was recorded at early of the stationary phase of $9^{\text {th }}$ day while the maximum growth of cells were observed at late $\log$ phase of $7^{\text {th }}$ day with $1.98 \pm 1.7 \mu \mathrm{g} / \mathrm{g}$ dry cell weight and production of the t-resveratrol $172 \pm 1.6$ $\mu \mathrm{g} / \mathrm{g}$ and $\alpha$-viniferin $180 \pm 1.3 \mu \mathrm{g} / \mathrm{g}$ while early of stationary phase $9^{\text {th }}$ day the production of t-resveratrol and $\alpha$-viniferin was recorded $300 \pm 2.3 \mu \mathrm{g} / \mathrm{g}$ and $324 \pm$ $2.6 \mu \mathrm{g} / \mathrm{g}$. Middle of the stationary phase $11^{\text {th }}$ day cell growth and mass was noticeably decreases, $1.74 \pm 1.8 \mu \mathrm{g} / \mathrm{g}$ dry cell weight with less production of the $\mathrm{t}$ resveratrol $100 \mu \mathrm{g} / \mathrm{L}$ and $\alpha$-viniferin $143 \mu \mathrm{g} / \mathrm{g}$. While synthesis of t-resveratrol and $\alpha$-viniferin started from the lag phase of cultivation and the maximum value reached on early of the stationary phase of cultivation both intracellular and extracellular. In log phase, more growth was observed and in early stationary phase of cell cycle, more accumulation of t-resveratrol and $\alpha$-viniferin was observed on day 9 , both growth and production of the compounds was declined in late stationary phase on day 13 (Table III). Simultaneously t-resveratrol and $\alpha$ viniferin amount inside and outside the cell was studied and no compound was detected in spent medium proved that fungal mycelium secreted both the compounds. Therefore, t-resveratrol and $\alpha$-viniferin may be a constitutive product that accumulates within cells of Aspergillus stellifer AB4 (Figure IV).

Table 3 Cell culture growth pattern of Aspergillus stellifer AB4 for resveratrol and viniferin production

\begin{tabular}{llll}
$\begin{array}{l}\text { Sample } \\
\text { collection } \\
(\text { days })\end{array}$ & $\begin{array}{l}\text { Cell dry weight } \\
(\mu \mathrm{g} / \mathrm{g})\end{array}$ & $\begin{array}{l}\text { t-resveratrol } \\
(\mu \mathrm{g} / \mathrm{L})\end{array}$ & $\begin{array}{l}\alpha \text {-viniferin } \\
(\mu \mathrm{g} / \mathrm{L})\end{array}$ \\
\hline 5 & $1.91 \pm 2.36$ & $161 \pm 2.31$ & $168 \pm 3.21$ \\
7 & $1.98 \pm 2.22$ & $172 \pm 1.61$ & $180 \pm 1.30$ \\
9 & $1.80 \pm 2.1$ & $300 \pm 2.31$ & $\mathbf{3 2 4} \pm 2.6$ \\
11 & $1.74 \pm 3.2$ & $100 \pm 1.64$ & $143 \pm 2.11$ \\
13 & $1.00 \pm 2.1$ & $23 \pm 2.22$ & $41 \pm 2.00$ \\
\hline
\end{tabular}
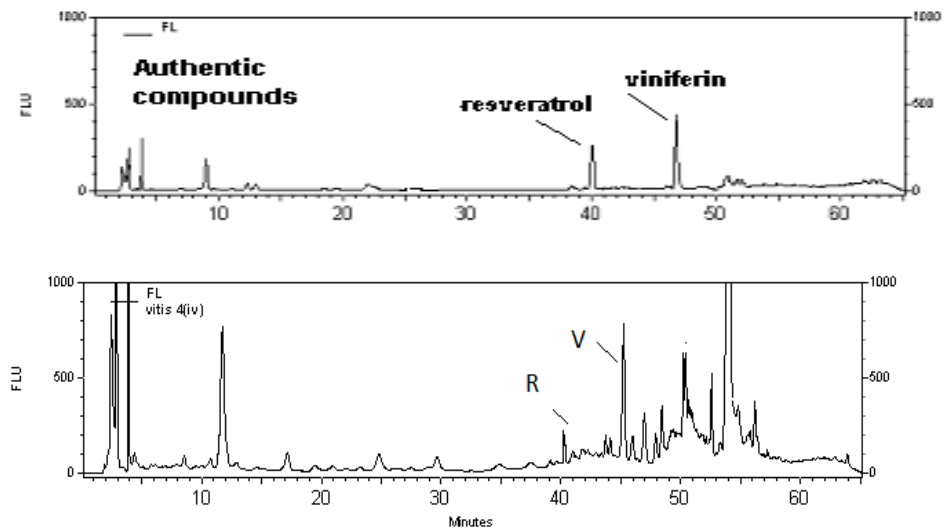

Figure 4 HPLC Profile of t-resveratrol and $\alpha$-viniferin in Aspergillus stellifer $\mathrm{AB} 4$ culture 
Optimization of physicochemical parameters for production of t-resveratrol and $\alpha$-viniferin

The optimum temperature was recorded at $28{ }^{\circ} \mathrm{C}$, with highest t-resveratrol production $(299 \mu \mathrm{g} / \mathrm{L})$ and $(322 \mu \mathrm{g} / \mathrm{L})$ of $\alpha$-viniferin with maximum growth $(1.97$ $\mathrm{mg} / \mathrm{ml}$ ) by isolated strain Aspergillus stellifer $\mathrm{AB} 4$. Whereas at $35^{\circ} \mathrm{C}$ the growth of cells was recorded less $1.30 \mathrm{mg} / \mathrm{ml}$ and less production of t-resveratrol $(157.46$ $\mu \mathrm{g} / \mathrm{L})$ and $\alpha$-viniferin $(179.0 \mu \mathrm{g} / \mathrm{L}$ ) (Figure $\mathrm{V}$ a). Likewise, very less growth and less bioactive metabolite production observed at low temperature $15^{\circ} \mathrm{C}$ and at high temperature $48^{\circ} \mathrm{C}$. The time course study were studied from temperature 15 ${ }^{\circ} \mathrm{C}$ to $48^{\circ} \mathrm{C}$, and it was noted that growth of A. stellifer $\mathrm{AB} 4$ cells ceased at 42 ${ }^{\circ} \mathrm{C}$. The design experiments proved that low temperature may stop the enzymes activity which involved in the metabolism of the fungus and high temperature may degraded the fungus. Similarly, (Shi et al., 2012) also reported the isolation of antifungal and antitumor agent from endophytic fungi at $25{ }^{\circ} \mathrm{C}$ and $7-9$ days of incubation period

The neutral pH-7 was recorded best for growth $(1.90 \mathrm{mg} / \mathrm{ml})$ and production of the molecules, $300 \mu \mathrm{g} / \mathrm{L}$ t-resveratrol and $324 \mu \mathrm{g} / \mathrm{L} \alpha$-viniferin by A. stellifer $\mathrm{AB} 4$ (Figure $\mathrm{V}$ b), the cell growth was increased from $\mathrm{pH}-5$ to 7 and then slight decline in growth at $\mathrm{pH}-9$, this study suggested that growth and bioactive metabolite production was also there to the more and less of $\mathrm{pH}-7$. But highly acidic $\mathrm{pH} 3$ and highly alkaline $\mathrm{pH} 11$ were not supported the growth and production of the compounds. Shin $\mathbf{J}$ et al., 2012, also, reported that highest production of t-resveratrol by Alternaria sp. MG1 was at $\mathrm{pH} 7 . \mathrm{pH}$ act significant role for the metabolism and or the biosynthesis of secondary metabolites because it is connected with cell wall and permeability properties of the cell membrane for ion uptake or loss to the nutrient medium. Rubini MR $\boldsymbol{e}$ al., 2005 reported the growth of endophytic fungal community and its antibacterial compounds production at neutral $\mathrm{pH}$.

The growth of cells, in terms of incubation time started from the initial stage of $\log$ phase, and the maximum growth was observed at late log and early stationary phase. In the present study maximum growth $1.98 \mu \mathrm{g} / \mathrm{L}$ was observed at 7 day and maximum production was recorded at 9 day, $300 \mu \mathrm{g} / \mathrm{L}$ t-resveratrol and $324 \mu \mathrm{g} / \mathrm{L}$ $\alpha$-viniferin by A. stellifer AB4 (Figure V c). Growth of cells is declined at early of stationary phase, while production enhanced at its maximum value, and at the end of the stationary phase both growth and production of compounds were significantly decreased. Stinson et al (Thakur et al., 2009) also reported similar results in the case of endophyte Gliocladium sp. Effect of incubation period on the production of bioactive compound (Fumonisin B1) by Fusarium moniliforme was investigated by (Albert $\boldsymbol{e t}$ al., 1990). They observed that the production of metabolite commenced after 12 days.

The inoculums size has significant role in growth and production of metabolites. More the inoculums size, more is the growth of cell but not necessary more the production of the compound because at early stationary phase growth was decline and production of metabolites was enhanced. Thakur et al., 2009 also reported the importance of inoculum density in increasing mycelia growth and metabolite production by Streptomyces species. In the present study, it was observed that the optimum inoculum size of $10 \%\left(2 \times 10^{4}\right.$ spores $\left./ \mathrm{ml}\right)$ was optimum for maximum growth and yield of metabolite by the Aspergillus stellifer AB4 (Figure V d).

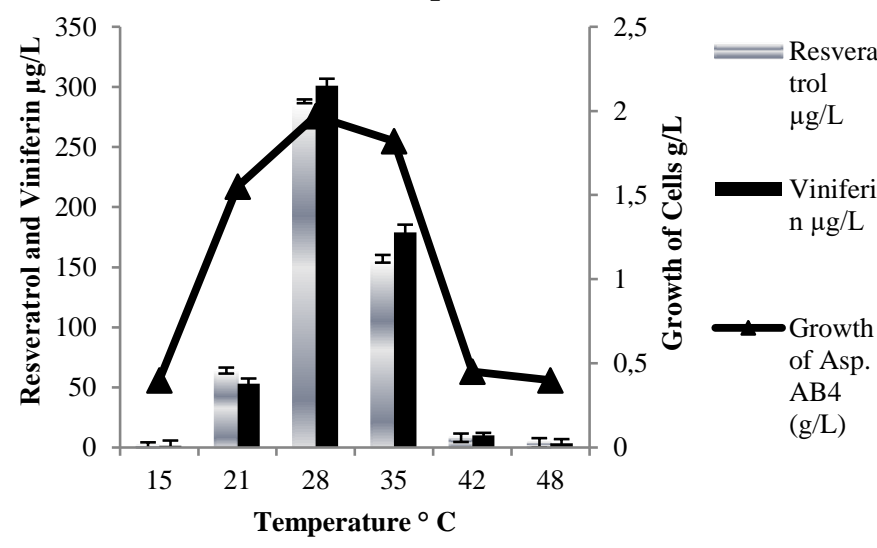

(B)
Effect of pH

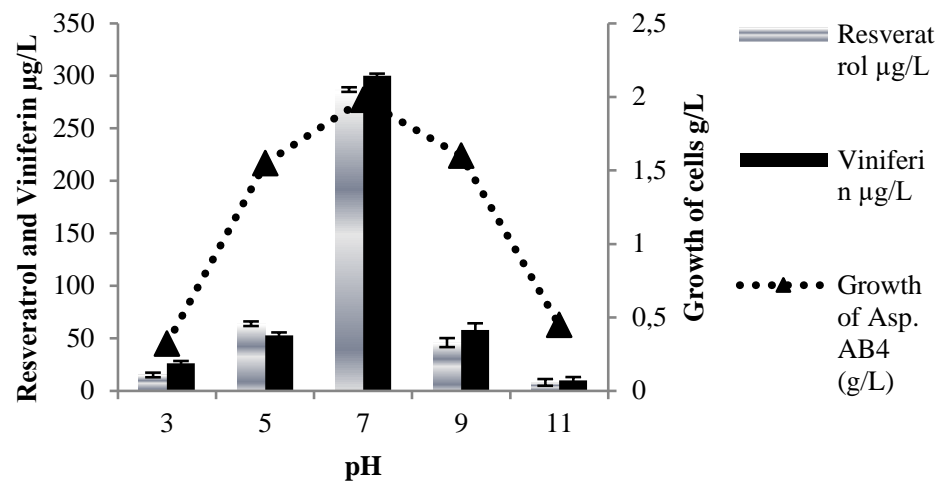

(C)

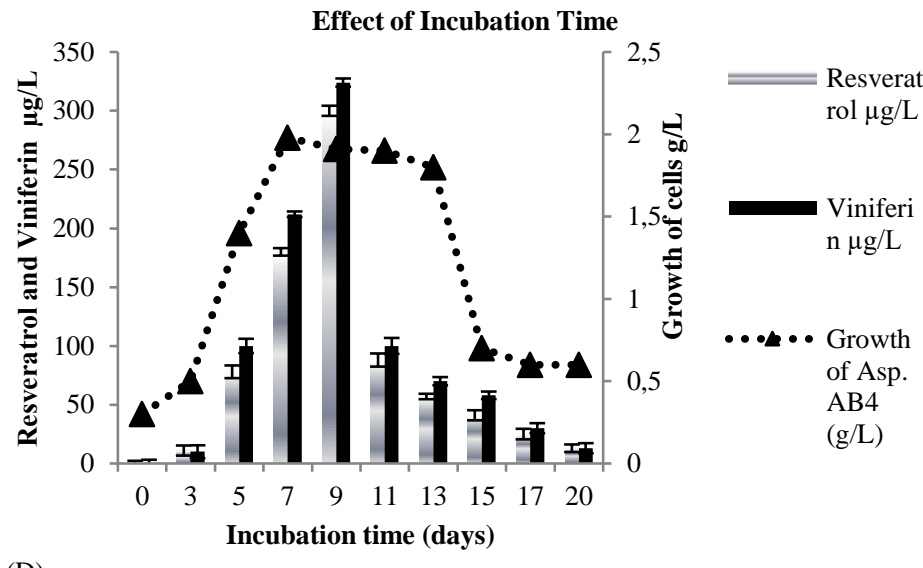

Effect of Inoculum Size
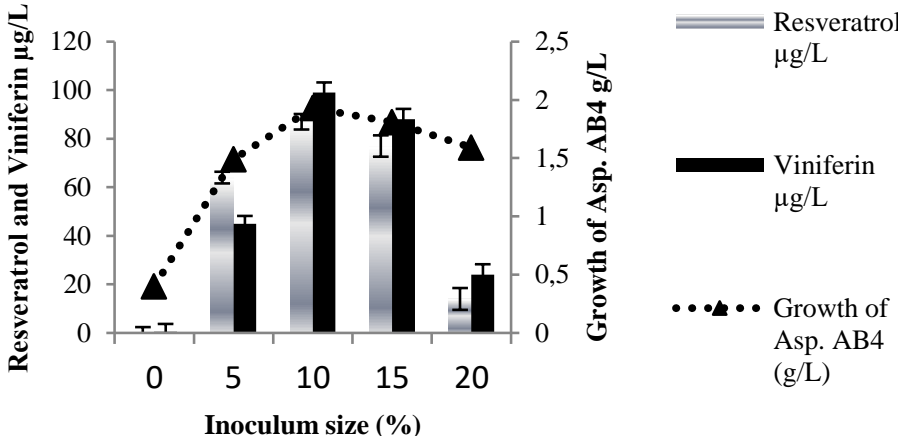

Figure 5 Optimization of physicochemical factors for production of t-resveratrol and $\alpha$-viniferin by Aspergillussp. AB4 (A) Incubation temperature (B) $\mathrm{Ph}(\mathrm{C})$ Incubation time (D) Inoculum size

Plants are very well known for secondary metabolites production in pharmaceutical and neutracuticals science. But plant both in vivo and in vitro take time to grow and produce the bioactive compounds. The in-vitro culture of Cayratia trifolia in MS medium containing $0.25 \mathrm{mg} \mathrm{1-1}$ of NAA and $0.2 \mathrm{mg} \mathrm{1-1}$ Kinetin after 15 -day cultures produced t-resveratrol, $35 \mu \mathrm{g} / \mathrm{l}$ and $\alpha$-viniferin, $182 \mu \mathrm{g} / 1$ (Roat et al., 2009). The endophytic microorganisms resides inside the plant tissue adapt the plant machinery and can able to produce the secondary metabolite in very short period of time, which the plant produced (Jasim et al 2013). Production of these bioactive compounds from endophytes is new and acceptable challenge in pharmaceutical world. Among the endophytes, fungus is very well known for the production of many novel secondary metabolites like polyphenols (Aly et al., 2011)

The medium and the explants selection plays important role for the production of the bioactive compounds, only appropriate medium along with appropriate plant part helps to isolated the endophytes and then, production of the bioactive molecules. Among all endophytic microorganisms, fungi have huge diversity in different plant in different or same geographical area. (Goldberd et al., 1996; Wang et al., 2010). In the present study, the fungal stain $\mathrm{AB} 4$ isolated from leaf of the Vitis vinifera capable to produced t-resveratrol and $\alpha$-viniferin from first to 
third and then subsequent subculture, while other isolated strain also produced these compounds but in less quantity and some isolates stop producing the compound after second subculture, Wang et al., 2010, also reported the similar result in endophytic fungus Tubercularia sp. TF5. The reason might be due to the enzymes or genes involvement in the biosynthesis of the compounds. Increased biomass and growth of Aspergillus cell supported the statement that t-resveratro and $\alpha$-viniferin is synthesized by Aspergillus strain AB4 .The findings revealed that t-resveratrol and $\alpha$-viniferin producing microorganisms are present in the nature. But simultaneously Aspergillus produced toxin and also act as a pathogen and non-pathogen for plants by Gonzalez and Tello, (2011). In this study the tresveratrol and $\alpha$-viniferin producing capability by Aspergillus sp. indicated the possibility of new genes and enzymes mechanism for the biosynthesis of bioactive molecules in endophytic microorganisms.

Physicochemical parameters like inoculum size, temperature, $\mathrm{pH}$, size of flasks were studied and optimized for the maximum production of t-resveratrol and $\alpha$ viniferin by Aspergillus stellifer AB4. The effect of temperature and $\mathrm{pH}$ for the production of t-resveratrol and $\alpha$-viniferin is depends on adaptability of the strain The optimum temperature for t-resveratrol and $\alpha$-viniferin production was the same as that for the cell growth of Alternaria sp. MG1 at $28{ }^{\circ} \mathrm{C}$ and $\mathrm{pH} 7$. The inoculums size and time period is also important for synthesis of these bioactive compounds because low inoculums sizes resulted in less of cell growth and high inoculums sizes revealed more cell degradation (Rubini et al., 2005). In the current study, we first time report the Aspergillus stellifer AB4 as the nove source for production of bioactive secondary metabolites resveratrol and $\alpha$ viniferin from Vitis vinifera plant in CYE medium. The presented data show new potential for improving the t-resveratrol and $\alpha$-viniferin production capability may be achievable given appropriate physicochemical conditions and for the enhancement for the production polyphenols: t-resveratrol and $\alpha$-viniferin.

\section{CONCLUSION}

In the current study, we report the Aspergillus stellifer AB4 from the plant Vitis vinifera as the source for production of secondary metabolites t-resveratrol and $\alpha$ viniferin on Czapek yeast extract medium. t-resveratrol and $\alpha$-viniferin have a significant roles in pharmaceutical and nutraceutical science. The presented data showed that the endophytic fungus Aspergillus stellifer $\mathrm{AB} 4$, has a potential for improving the $t$-resveratrol and $\alpha$-viniferin production in short period of time. The optimization studies of physicochemical conditions could help in large-scale production for both the molecules. We have studied an effective production of $\mathrm{t}$ resverarol is $300 \mu \mathrm{g} / \mathrm{L}$ and $\alpha$-viniferin is $324 \mu \mathrm{g} / \mathrm{L}$ from Aspergillus stellifer $\mathrm{AB} 4$, The high growth rate and short generation time suggests that Aspergillus stellifer $\mathrm{AB} 4$ could be promising source of t-resveratrol and $\alpha$ viniferin production. However, for the commercial development for the production of t-resveratrol and $\alpha$-viniferin, requires a combination of biotechnological approaches such as genetic manipulation, strain improvement and fermentation.

Acknowledgments: This work was supported by the University gran Commission, Government (UGC), New Delhi, India for providing Dr. D.S Kothari Post Doctoral Fellowship with Ref. No.F.4-2/3006(BSR)/BL/1617/0021\&01-09-2063

\section{REFERENCES}

Alberts, J.F., Gelderblom, W. C., Gthiel, P.G., Marasas, W.F., Schalkwyk, D. J. V., Behrend, D. J. V. (1990). Effects of temperature and incubation period on production of Fumonisin B1 by Fusarium moniliforme. App Environ Microbiol, 56:1729-1733.

Aly, A. H., Debbab, A., Proksch, P. (2011). Fungal endophytes: unique plan inhabitants with great promises. Appl Microbiol Biotechnol, 90:1829-1845. https://dx. doi.org/ 10.1007/s00253-011-3270-y

Baur, J.A., Sinclair, D.A. (2006). Therapeutic potential of resveratrol: the in vivo evidence. Nat Rev Drug Discov 5:493-506. . https://dx. doi.org/ 10.1038/nrd2060 Cherniack, E. P. (2011). Polyphenols: planting the seeds of treatment for the metabolic syndrome.Nutrition, 27: 617-623. https://dx. doi.org/ 10.1016/j.nut.2010.10.013

Chen, Y. J., Chen, Y.Y., Lin, Y.F., Hu, H. Y., Liao, H F. (2013). T-resveratro inhibits alpha-melanocyte-stimulating hormone signaling, viability, and invasiveness in melanoma cells. Evid Based Complement Alternat Med. 632121 https://dx. doi.org/10.1155/2013/632121

Dey, P., Banerjee, J.D., Maiti, M.K. (2011). Comparative lipid profiling of two endophytic fungal isolates Colletotrichum sp. and Alternaria sp. having potential utilities as biodiesel feed stock. Bioresoure Technol 102:5815-5823. https://dx. doi.org/10.1016/j.biortech.2011.02.064

Goldberd, D., Tsang, E., Karumanchiri, A., Diamandis, E., Soleas, G., NG, E. (1996). Method to assay the concentrations of phenolic constituents of biologica interest in wines. Anal. Chem. 68:1688-1694. https://doi.org/10.1021/ac951083i Huang, Y., Wang, J., Li, G. Zheng, Z.S.W. (2001). Antitumor and antifungal activities in endophytic fungi isolated from pharmaceutical plants Taxusmairei,
Cephalataxus fortune and Torreya grandis. FEMS. Immunol Med Microbiol 31:163-167. https://dx. doi.org/10.1111/j.1574-695X.2001.tb00513.x

Jasim, B., Joseph, A.A., John, C.J., Mathew, J., Radhakrishnan, E.K. (2014) Isolation and characterization of plant growth promoting endophytic bacteria from the rhizome of Zinger officinal. 3Biotech 4:197-204. https://dx. doi.org/ $10.1007 / \mathrm{s} 13205-013-0143-3$

Larran, S., Perello, A., Simon, M.R., Moreno, V. (2002). Isolation and analysis of endophytic microorganisms in wheat (Triticumaestivum L.) leaves. World Journal of Microbiology \& Biotechnology, 18: 683-686. . https://dx. doi.org/ 10.1023/A:1016857917950

Naik, B.S., Sashikala, J., Krishnamurthy, Y.L. (2009). Study on the diversity of endophytic communities from rice (Oryzasativa L) and their anatagonistic activities in vitro. Microbiological Research. 164(3):290-296. . https://dx. doi.org/ 10.1016/j.micres.2006.12.003

Nonomura, S., Kanagawa, H., Makimoto, A. (1963). Chemical constituents of polygonaceous plants. I. Studies on the components of Ko-J O-Kon. (Polygonum cuspidatum Sieb. Et Zucc.). Yakugaku Zasshi 83:988-990. https://doi.org/10.1248/yakushi1947.83.10_988

Pereyra, C.M., Cavaglieri, L.R., Chiacchiera, S.M., Dalcero, A.M. (2011) Mycobiota and mycotoxins contamination in raw materials and finished feed intended for fattening pig's production in eastern Argentina. Vet Res Commun 35:367. https://doi.org/10.1007/s11259-011-9483-9

Roat, C., Ramawat, K. G. (2009). Elicitor induced accumulation of stilbenes in cell suspension cultures of Cayratia trifolia (L.) Domin. Plant Biotechnol Rep. 135-138. https://doi.org/10.1007/s11816-009-0082-y

Rubini, M.R., Rute, T.S.R, Pomella, A.W., Cristina, S.M., Arajo, L.W., Santos, D.R.D., Azevedo, J.L. (2005). Diversity of endophytic fungal community of cocao (Thebroma cacao L.) and biological control of Crinipellis perniciosa, causal agent of Witches' Broom disease. Int $J$ Bio Sci, 1:24-33 https://doi.org/10.7150/ijbs.1.24

Saitou, N., Nei, M. (1987). The neighbor-joining method: a new method for reconstructing phylogenetic trees. Mol Biol Evol. 4:406-425 https://doi.org/10.1093/oxfordjournals.molbev.a040454

Shi, J., Zeng, Q., Liu, Y., Pan, Z. (2012). Alternaria sp. MG1, a t-resveratrolproducing fungus: isolation, identification, and optimal cultivation conditions for t-resveratrol production. Appl Microbial Biotechnol. 95: 369-379. https://doi.org/10.1007/s00253-012-4045-9

Stinson, M., Ezra, D., Hess, W.M., Sears, J., Strobel, G. A (20030. An endophytic Gliocladium sp. of Eucryphia cordifolia producing selective volatile antimicrobial compounds. Plant Sci. 165: 913-922. https://doi.org/10.1016/S0168-9452(03)00299-1

Suetsuna, K., Osajima, Y. (1990). Cultural conditions for production of griseorhodin by a culture of Streptomyces californicus JCM6910. Suisan Diagakkakenkyn Hokoku. 38: 17-22

Tamura, T., Dudley, J., Nei, M., Kumar, S. (2007). MEGA 4: molecular evolutionary genetic analysis (MEGA) software version 4.0. Mol Biol Evol, 24:1596-1599. https://doi.org/10.1093/molbev/msm092

Thakur, D., Bora, T. C., Bordoloi, G.N. Mazumdar S. (2009). Influence of nutrition and culture in conditions for optimum growth and antimicrobia metabolite production by Streptomyces sp.301. J Med Mycol. 19:161-167. https://doi.org/10.1016/j.mycmed.2009.04.001

Thompson, J., D., Gibson, T. J., Plewniak, F., Jeanmougin, F., Higgins, D. G. (1997). The Clustal X windows interface: flexible strategies for multiple sequence alignment aided by quality analysis tools. Nucleic Acids Res, 25:4876 4882. https://doi.org/10.1093/nar/25.24.4876

Wang, M.Z., Liu, S.S, Li,Y.Y., Xu, R.L.C., Shen, Y.M. (2010). Protoplast mutation and genome shuffling induce the endophytic fungus Tubercularia $\mathrm{sp}$ TF5 to produce new compounds. Curr Microbiol 6:254-260. https://doi.org/10.1007/s00284-010-9604-7

Xianfeng-Huang, X.H., Zhu, H.L. (2011). t-resveratrol and its analogues: promising antitumor agents, Anticancer Agents. Med Chem., 11: 479-490.

Xing, X.K., Guo, S.X. (2011). Fungal endophyte communities in four Rhizophoraceae mangrove species on the south coast of China. Ecol Res 26:403 409. https://doi.org/10.1007/s11284-010-0795-y

Yuan, Z.L., Rao, L.B., Chen, Y.C., Zhang, C.L., Wu, Y.G. (2011).From pattern to process: species and functional

diversityin fungal endophytes of Abies beshanzuensis. Fungal 115:197-213 https://doi.org/10.1016/j.funbio.2010.11.002

Zhu, X., Liu, Q., Wang, M., Liang, M., Yang, X., Xu, X. (2011). Activation of Sirt1 by resveratrol inhibits TNF-alpha induced inflammation in fibroblasts. PLoS ONE 6: 270-81. https://doi.org/10.1371/journal.pone.0027081 